\title{
THE EFFECTIVENESS OF MULTICULTURAL BASED INDONESIAN TEACHING MATERIALS TO IMPROVE CRITICAL THINKING SKILLS
}

\author{
Sony Ari Wibowo ${ }^{1}$, Murtono $^{2}$, dan Sri Utaminingsih ${ }^{3}$ \\ 1,2,3 Universitas Muria Kudus, Indonesia \\ ${ }^{1}$ sony.ariwibowo@umk.ac.id, ${ }^{2}$ murtono@umk.ac.id, ${ }^{3}$ sri.utaminingsih@umk.ac.id
}

\begin{abstract}
This study aimed to describe the effectiveness of multicultural-based Indonesian teaching materials to improve students' critical thinking skills at grade IV elementary schools in Kabupaten Jepara. The type of this study was Research and Development $(R \& D)$. The teaching materials were tested at grade 1 SD Tritis and SD 1 Karangnongko as the experiment groups and SD 1 Daren and SD 3 Nalumsari as the control groups. Data collection was conducted through observation, interviews, and documentation. Indonesian teaching materials were developed based on the multicultural based Indonesian teaching materials on the theme 4 "various jobs"at grade IV elementary school. Results showed that multicultural based Indonesian teaching materials was effective to enhance the students' critical thinking skills at grade IV elementary schools in Kabupaten Jepara. The results of $t$-test on the experimental and control groups was 8.994, which indicated that $t_{\text {count }}>t_{\text {table }}(8.994>1.699)$. Hence, Ho was rejected and $\mathrm{Ha}$ was accepted. Based on this result, it could be concluded that utilizing multicultural based Indonesian teaching materialswas effective and fit to improve the students' critical thinking skills at grade IV elementary schools in Kabupaten Jepara.
\end{abstract}

Keywords: teaching materials, multicultural, critical thinking

\section{EFEKTIVITAS PENGGUNAAN BAHAN AJAR BAHASA INDONESIA BERBASIS MULTIKULTURAL UNTUK MENINGKATKAN KETERAMPILAN BERPIKIR KRITIS}

\begin{abstract}
ABSTRAK
Penelitian ini bertujuan untuk mendeskripsikan efektivitas bahan ajar Bahasa Indonesia berbasis multikultural untuk meningkatkan keterampilan berpikir kritis siswa kelas IV Sekolah Dasar di Kabupaten Jepara. Jenis penelitian yang digunakan dalam penelitian ini adalah Research and Development (R \& D). Bahan ajar ini di uji cobakan di kelas IV SD 1 Tritis dan SD 1 Karangnongko sebagai kelompok eksperimen dan SD 1 Daren dan SD 3 Nalumsari sebagai kelompok kontrol di Kecamatan Nalumsari Kabupaten Jepara. Teknik pengumpulan data dalam penelitian ini dilakukan melalui observasi, wawancara, dan dokumentasi. Bahan ajar Bahasa Indonesia berbasis multikultural dikembangkan berdasarkan materi Bahasa Indonesia pada tema 4 berbagai pekerjaan di kelas IV sekolah dasar. Hasil Penelitian menunjukkan bahwa bahan ajar Bahasa Indonesia berbasis multikultural efektif digunakan untuk meningkatkan keterampilan berpikir kritis siswa kelas IV Sekolah Dasar di Kabupaten Jepara. Hasil dari uji-t pada kelompok eksperimen dan kontrol yaitu 8.994. Adapun hasil uji-t didapatkan bahwa $t_{\text {hitung }}>\mathrm{t}_{\text {tabel }}$ yaitu $8.994>1.699$, maka sebagaimana dasar pengambilan keputusan dapat disimpulkan bahwa Ho ditolak dan Ha diterima. Dengan demikian, dapat disimpulkan bahwa penerapan bahan ajar Bahasa Indonesia berbasis multikultural efektif dan layak digunakan dalam meningkatkan keterampilan berpikir kritis siswa kelas IV Sekolah Dasar di Kabupaten Jepara.
\end{abstract}

Kata Kunci: bahan ajar, multikultural, berpikir kritis

\begin{tabular}{|c|c|c|}
\hline Submitted & Accepted & Published \\
\hline 21 Januari 2020 & 10 Maret 2021 & 28 Maret 2021 \\
\hline
\end{tabular}

\begin{tabular}{|l|c|c|}
\hline Citation & $:$ & $\begin{array}{r}\text { Wibowo, S.A., Murtono., \& Utaminingsih, S. (2021). The Effectiveness of Multicultural Based Indonesian } \\
\text { Teaching Materials to Improve Critical Thinking Skills. Jurnal PAJAR (Pendidikan dan Pengajaran), } \\
5(2), 403-411 . \text { DOI : http://dx.doi.org/10.33578/pjr.v5i2.8287. }\end{array}$ \\
\hline
\end{tabular}

\section{PENDAHULUAN}

Sekolah dasar merupakan momentum awal bagi anak untuk meningkatkan kemampuan dirinya. Dari bangku sekolah dasarlah mereka mendapatkan imunitas belajar yang kemudian menjadi kebiasaan-kebiasaan yang akan mereka lakukan di kemudian hari. Sekolah dasar merupakan salah satu lembaga pendidikan formal yang bertugas membentuk karakter pengetahuan, sikap, dan keterampilan dasar siswa guna menyiapkan untuk melanjutkan kejenjang yang lebih tinggi. Sebagai tempat awal peningkatan kualitas sumber daya manusia, maka diperlukan 
upaya-upaya untuk meningkatkan kualitas pembelajaran di sekolah dasar agar pembelajaran dapat berjalan dengan efektif dan efisien. (Khakim, 2014), menjelaskan sekolah dasar senantiasa mengadakan peningkatan dan penyempurnaan mutu pendidikan untuk dapat mencapai tujuan pendidikan secara optimal, salah satunya melalui peningkatan kualitas kegiatan pembelajaran. Proses pendidikan mengalami perkembangan sesuai dengan proses perkembangan zaman. Perkembangan pendidikan pada era globalisasi menuntut para ahli dalam bidang pendidikan untuk mengembangkan berbagai inovasi untuk memajukan siswa yang berkualitas dan berkarakter. (Hamalik, 2015), menyatakan pengajaran yang efektif adalah pengajaran yang menyediakan kesempatan belajar sendiri atau melakukan aktivitas sendiri. Pembelajaran yang bermakna yaitu pembelajaran yang berpusat pada siswa, sistem pembelajaran yang mengarahkan keterpusatan kepada siswa akan dapat menumbuhkan dan mengembangkan kreativitas dan melatih kemampuan berpikir kritis siswa dalam pembelajaran maupun dalam memecahkan permasalahan yang dihadapi dalam kehidupan sehari-hari.

Keterampilan berpikir kritis perlu dikembangkan dalam diri siswa karena melalui keterampilan berpikir kritis, siswa dapat lebih mudah memahami konsep, peka akan masalah yang terjadi sehingga dapat memahami dan menyelesaikan masalah, dan mampu mengaplikasikan konsep dalam situasi yang berbeda. (Susanto, 2016), menjelaskan berpikir kritis merupakan suatu kegiatan melalui cara berpikir tentang ide atau gagasan yang berhubungan dengan konsep yang diberikan atau masalah yang dipaparkan. Sedangkan (Ennis dalam Permana, Iin, Ndzani, dan Ardianti, 2019), menjelaskan critical thinking skills could be defined as logical and reflective thinking skills that focus on determining what must be done. Lebih lanjut (Surya, 2016), menjelaskan berpikir kritis merupakan salah satu strategi kognitif dalam pemecahan masalah yang lebih kompleks dan menuntut pola yang lebih tinggi. (Kuswana, 2013), menyatakan menggunakan kemampuan berpikir kritis yang kuat memungkinkan kita untuk mengevaluasi argumen, dan layak untuk penerimaan berdasarkan pikirannya. (Susanto, 2016), menjelaskan lima indikator dari masingmasing aspek berpikir kritis yang berkaitan dengan materi pelajaran, yaitu (1) Memberikan penjelasan sederhana, (2) Membangun keterampilan dasar, (3) Menyimpulkan, (4) Memberikan penjelasan lanjut, dan (5) Mengatur strategi dan taktik. Keterampilan berpikir kritis siswa perlu dikembangkan mulai dari sekolah dasar melalui pembiasaan-pembiasaan dalam pembelajaran, pembiasaan dalam proses pembelajaran akan meningkatkan keterampilan berpikir kritis siswa. Salah satu materi pembelajaran yang perlu disisipkan keterampilan berpikir kritis siswa dalam pembelajaran yaitu mata pelajaran Bahasa Indonesia pada Tema 4 Berbagai Pekerjaan di kelas IV. Materi dalam tema 4 ini sangat dekat dengan segala aktivitas masyarakat sehari-hari begitu pula dengan lingkungan siswa.

Berdasarkan hasil studi pendahuluan diketahui bahwa masih banyak siswa yang belum dapat memahami materi yang diajarkan oleh guru, yang membuat siswa merasa terbebani dalam pembelajaran dan menghambat pengembangan keterampilan berpikir kritis siswa. siswa pasif dalam kegiatan pembelajaran, sehingga proses pembelajaran belum terpusat pada siswa sebagai objek. Guru sudah berinovasi dalam mengembangkan kegiatan pembelajaran dengan menggunakan beberapa model pembelajaran tetapi belum maksimal, dan guru belum menggunakan media pembelajaran secara optimal. Dilihat dari segi bahan bacaan dan teks pendukung yang tersedia dalam buku siswa dan buku guru masih belum sesuai dengan lingkungan yang dihadapi oleh siswa. Bahan bacaan dan teks pendukung kurang menyisipkan pendidikan mutikultural dan kurang mencerminkan permasalahan yang ada secara nyata di lingkungan sekitar siswa, hal ini mengakibatkan pembelajaran kurang kontekstual dengan pengalaman hidup siswa yang sebenarnya. Dilihat dari Keberagaman yang ada, ditemukan keberagaman gender laki-laki dan perempuan, ras kulit putih dan hitam, ras rambut lurus dan kriting, strata sosial, dan agama, hal ini 
tentu perlu pemahaman akan keberagaman yang muncul pada tiap-tiap siswa.

Sebagai salah satu alternatif untuk mengatasi kelemahan-kelemahan dalam peningkatan keterampilan berpikir kritis berkaitan dengan proses pembelajaran diperlukan sebuah pengembangan bahan ajar yang menarik sehingga mampu mendorong siswa untuk meningkatkan keterampilan berpikir kritisnya. (Prastowo, 2011), menyatakan bahan ajar merupakan segala bahan (baik informasi, alat, maupun teks) yang disusun secara sistematis, yang menampilkan sosok utuh dari kompetensi yang akan dikuasai siswa dan digunakan dalam proses pembelajaran dengan tujuan perencanaan dan penelaahan implementasi pembelajaran. bahan ajar adalah sebuah persoalan pokok yang tidak bisa dikesampingkan dalam satu kesatuan pembahasan yang utuh tentang cara pembuatan bahan ajar. (Koparan, 2017), menjelaskan using materials have diret effects on realization of educative purposes in the teaching and learning process. (Yaumi, 2016), menjelaskan bahan ajar merupakan seperangkat bahan yang disusun secara sistematis untuk kebutuhan pembelajaran yang bersumber dari bahan cetak, alat bantu visual, audio, video, multimedia dan animasi, serta komputer dan jaringan. (Susiana, 2017), menjelaskan bahan ajar merupakan bahan belajar yang digunakan dalam aktivitas pembelajaran di kelas demi tercapainya tujuan pembelajaran. penyusunan bahan ajar disesuaikan dengan karakteristik dan tingkat kemampuan siswa. Dengan memperhatikan karakteristik dan tingkat kemampuan siswa, bahan ajar tersebut akan mudah dipahami oleh siswa. (Joni dalam Harijanto, 2007), menjelaskan bahan ajar mempunyai fungsi yang sangat penting dalam kegiatan pembelajaran, yaitu. (1) memberikan petunjuk yang jelas bagi pembelajar dalam mengelola kegiatan belajar mengajar, (2) menyediakan bahan/alat yang lengkap yang diperlukan untuk setiap kegiatan, (3) merupakan media penghubung antara pembelajar dan pebelajar, (4) dapat dipakai oleh pebelajar sendiri dalam mencapai kemampuan yang telah ditetapkan, dan (5) dapat dipakai sebagai program perbaikan. Pengembangan bahan ajar tematik melibatkan sejumlah langkah yang mesti ditempuh oleh seorang pengembang. (Dick dan Carey dalam Nai, 2016), menguraikan langkahlangkah pengembangan bahan ajar sebagai berikut (1) identifying learning objectives, (2) analyzing learning, (3) analyzin the learning and context, (4) formulating learning objectives, (5) developing the test items, (6) developinng learning strategies, (7) developing and selecting the content of learning program, (8) designing and implementing formative evaluation, (9) revising learning package, and (10) designing and implementing summative evaluation.

Pengembangan pembelajaran dalam penelitian ini berbasiskan pada pendidikan multikultural, perlu disadari proses pendidikan adalah proses pembudayaan dan cita-cita persatuan bangsa merupakan unsur budaya nasional. Akar kata multikulturalisme adalah kebudayaan. Secara etimologis multikulturalisme dibentuk dari kata multi (banyak), kultur (budaya), dan isme (aliran/paham). (Schlein dan Elaine, 2012), menjelaskan multiculturalism is defined as the most significant current societal issue of the epoch. (Khairuddin, 2018), menjelaskan secara sederhana multikulturalisme adalah sebuah paham yang membenarkan dan menyakini adanya relativisme kultur disebabkan adanya keragaman budaya, keragaman suku dengan kebudayaan khasnya. Dalam kehidupan bangsa yang multikultural dituntut adanya kearifan untuk melihat keanekaragaman budaya sebagai realitas dalam kehidupan bermasyarakat. Lebih lanjut (Jatmiko dan Ferry, 2006), menguraikan multikultural lebih sekedar pengakuan tetapi membuka ruang untuk akses dan berekspresi bagi semua elemen keanekaragaman tersebut dengan bersandar pada jati diri masing-masing, dan kemudian saling berkomunikasi tanpa harus saling mematikan satu sama lain. Multikulturalisme mengakui berbagai potensi dan legimitasi keragaman dan perbedaan sosio-kultural tiap-tiap kelompok etnis, ras, agama, dan entitas kebudayaan. (Khairuddin, 2018), menyatakan pendidikan multikultural adalah usaha sadar untuk mengembangkan kepribadian di dalam dan di luar sekolah yang mempelajari tentang berbagai macam status 
sosial, ras, suku, agama agar tercipta kepribadian yang cerdas dalam menghadapi masalah-masalah keberagaman budaya. (Lee, 2019), menyatakan secara khusus guru harus berpartisipasi dalam keterlibatan berkelanjutan untuk memahamkan pada diri siswa tentang perbedaan yang ada misalnya prestasi. (Nurcahyono, 2018), menjelaskan pada prinsipnya pendidikan multikultural mendambakan persamaan hak, termasuk hak dalam mengakses pendidikan untuk semua orang. Indonesia merupakan masyarakat dengan tingkatan keanekaragman yang sangat komplek. (Alismail, 2016), menjelaskan salah satu tantangan lain dalam pendidikan multikultural adalah memberikan pendidikan yang adil bagi siswa dengan tujuan mencapai keadilan sosial.

Singkatnya pendidikan berbasis multikultural menginginkan terciptanya Bhineka Tunggal Ika yang sebenarnya dalam segala aspek kehidupan, utamanya dalam pendidikan. (Wahyuni, 2015), menguraikan tujuan pelaksanaan pendidikan multikultural, yaitu (1) memahami latar belakang diri dan kelompok dalam masyarakat, (2) menghormati dan mengapresiasi kebhinekaan budaya dan sosio historis etnik, (3) menyelesaikan sikap-sikap yang terlalu etnosentris dan penuh purbasangka, (4) memahami faktor-faktor sosial, ekonomis, psikologis, dan historis yang menyebabkan terjadinya polarisasi etnik ketimpangan dan keterasingan etnik, dan (5) meningkatkan kemampuan menganalisis secara kritis masalahmasalah rutin dan isu melalui proses demokratis melalui sebuah visi tentang masyarakat yang lebih baik, adil, dan bebas, (6) mengembangkan jati diri yang bermakna bagi semua orang. Lebih lanjut (Salmiwati dalam Nurjanah, Hamdan, dan Ufi, 2017), menjelaskan nilai-nilai dalam pendidikan multikultural sebagai berikut, (1) Nilai demokrasi, pendidikan hendaknya mengembangkan kemampuan untuk mengakui dan menerima nilai-nilai yang ada dalam kebhinekaan pribadi, jenis kelamin, masyarakat dan budaya serta mengembangkan kemampuan untuk berkomunikasi, berbagai dan bekerja sama dengan yang lain. (2) Nilai kesetaraan, pendidikan hendaknya meneguhkan jati diri dan mendorong konvergensi gagasan dan penyelesaian-peyelesaian yang memperkokok perdamaian, persaudaraan dan solidaritas antara pribadi dan masyarakat. Dan (3) Nilai keadilan, pendidikan hendaknya meningkatkan kemampuan menyelesaikan konflik secara damai tanpa kekerasan. Karena itu pendidikan hendaknya juga meningkatkan pengembangan kedamaian dalam pikiran siswa sehingga dengan demikian mereka mampu membangun secara lebih kokoh kualitas toleransi, kesabaran, kemauan untuk berbagi dan memelihara.

Penelitian pengembangan bahan ajar yang dilakukan oleh (Indrawini, 2017), dalam penelitiannya yang berjudul pengembangan bahan ajar tematik subtema ayo cintai lingkungan untuk siswa kelas IV SD. Hasil penelitian menunjukkan bahwa hasil validasi dan uji coba, bahan ajar tematik yang dikembangkan ini merupakan bahan ajar yang layak untuk digunakan dalam proses pembelajaran. Aspek kelayakan yang dimiliki bahan ajar yaitu kevalidan yang termasuk sangat valid dengan persentase sebesar $87.45 \%$, kepraktisan yang termasuk sangat praktis dengan persentase sebesar $94.43 \%$, dan keefektifan yang termasuk sangat efektif dengan persentase sebesar $81.1 \%$. Dengan demikian, bahan ajar ini dapat digunakan untuk mengisi kekurangan serta memperkaya sumber belajar yang sudah ada. Persamaan dengan penelitian yang penulis lakukan adalah pada pengembangan bahan ajar, sedangkan perbedaannya terletak pada peneliti mengembangkan bahan ajar pada satu subtema dan penulis mengembangkan pada satu tema dan focus pada mata pelajaran bahasa Indonesia.

Bahan ajar Bahasa Indonesia berbasis multikultural merupakan suatu solusi pengembangan pembelajaran yang cocok dalam meningkatkan keterampilan berpikir kritis siswa. Adanya bahan ajar ini, diharapkan mampu meningkatkan keterampilan berpikir kritis siswa dan menjadikan suatu pendidikan menjadi berkualitas. Berdasarkan hal tersebut, maka penelitian ini bertujuan untuk mendeskripsikan efektivitas penggunaan bahan ajar Bahasa Indonesia berbasis multikultural untuk 
meningkatkan keterampilan berpikir kritis siswa kelas IV Sekolah Dasar di Kabupaten Jepara.

\section{METODE PENELITIAN}

Jenis penelitian yang digunakan dalam penelitian ini adalah Research and Development (R \& D). Penelitian ini dilaksanakan di kelas IV SD 1 Tritis dan SD 1 Karangnongko, sebagai kelompok eksperimen dan SD 1 Daren dan SD 3 Nalumsari sebagai kelompok kontrol di Kecamatan Nalumsari Kabupaten Jepara. Penelitian ini dilaksanakan pada jadwal kegiatan kelas IV tema 4 berbagai pekerjaan mulai bulan Oktober sampai dengan bulan Desember tahun pelajaran 2019/2020. Teknik pengumpulan data dalam penelitian ini dilakukan melalui Observasi, Wawancara, dan Dokumentasi.

Observasi digunakan dengan melakukan pengamatan terhadap pembelajaran oleh guru dan siswa kelas IV SD di Kecamatan Nalumsari Kabupaten Jepara. Wawancara dalam penelitian ini ditujukan pada guru dan siswa kelas IV Sekolah dasar. Kemudian metode dokumentasi dilakukan untuk memperkuat data yang diperoleh dalam observasi. Teknik analisis data dalam penelitian ini dilakukan melalui uji normalitas, uji homogenitas, dan uji Uji $\mathrm{t}(t$-test $)$. Adapun rancangan penelitian ini dapat digambarkan dalam bagan berikut.

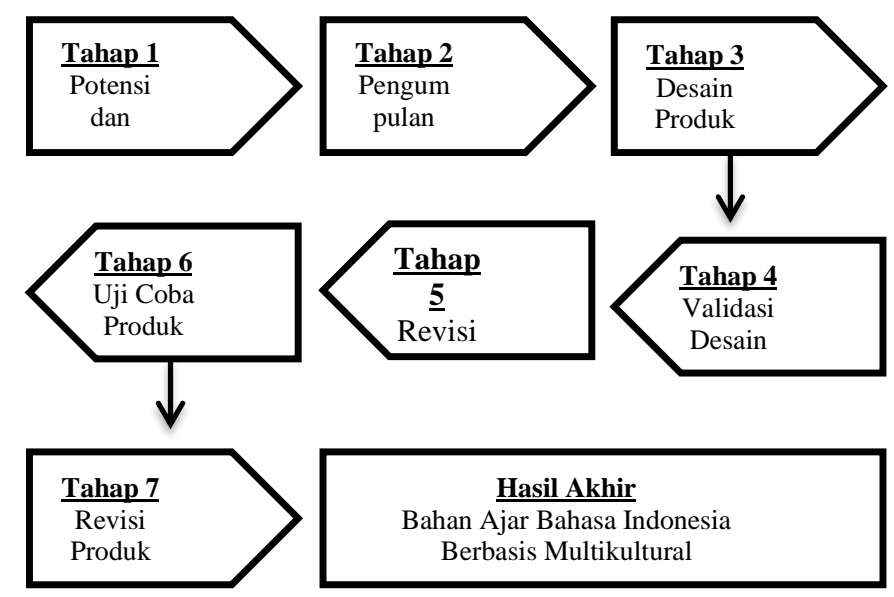

Gambar 1. Bagan Prosedur Penelitian

\section{HASIL DAN PEMBAHASAN}

Hasil analisis studi pendahuluan diperoleh data bahwa masih banyak siswa yang belum dapat memahami materi yang diajarkan oleh guru, yang membuat siswa merasa terbebani dalam pembelajaran dan menghambat pengembangan keterampilan berpikir kritis siswa, Hal ini dibuktikan dengan masih rendahnya nilai hasil belajar Bahasa Indonesia Tema 4 berbagai Pekerjaan siswa kelas IV. Kemudian siswa pasif dalam kegiatan pembelajaran, sehingga proses pembelajaran belum terpusat pada siswa sebagai objek. (Susanto, 2016), menjelaskan Berpikir kritis merupakan suatu kegiatan melalui cara berpikir tentang ide atau gagasan yang berhubungan dengan konsep yang diberikan atau masalah yang dipaparkan Berpikir kritis juga dapat dipahami sebagai kegiatan menganalisis ide atau gagasan ke arah yang lebih spesifik, membedakannya secara tajam, memilih, mengidentifikasi, mengkaji, dan mengembangkannya ke arah yang lebih sempurna.

Kemudian guru sudah berinovasi dalam mengembangkan kegiatan pembelajaran dengan menggunakan beberapa model pembelajaran tetapi belum maksimal, dan guru belum menggunakan media pembelajaran secara optimal. Selain itu dilihat dari segi bahan bacaan dan teks pendukung yang tersedia dalam buku siswa dan 
buku guru masih belum sesuai dengan lingkungan yang dihadapi oleh siswa. Bahan bacaan dan teks pendukung yang tersedia sering dieluhkan oleh beberapa guru dan siswa karena materi yang tersedia sangat kurang sehingga harus menggunakan bahan bacaan dan teks pendukung dari kurikulum terdahulu. (Susiana, 2017), menjelaskan Bahan ajar merupakan bahan belajar yang digunakan dalam aktivitas pembelajaran di kelas demi tercapainya tujuan pembelajaran. Bahan bacaan dan teks pendukung kurang menyisipkan pendidikan mutikultural dan kurang mencerminkan permasalahan yang ada secara nyata di lingkungan sekitar siswa, hal ini mengakibatkan pembelajaran kurang kontekstual dengan pengalaman hidup siswa yang sebenarnya. (Schlein, 2012), menjelaskan multiculturalism is defined as the most significant current societal issue of the epoch. Lebih lanjut (Khairuddin, 2018), menjelaskan secara sederhana multikulturalisme adalah sebuah paham yang membenarkan dan menyakini adanya relativisme kultur disebabkan adanya keragaman budaya, keragaman suku dengan kebudayaan khasnya. Dilihat dari Keberagaman yang ada, ditemukan keberagaman gender laki-laki dan perempuan, ras kulit putih dan hitam, ras rambut lurus dan kriting, anak bertubuh gemuk dan kurus, selain itu ditemukan perbedaan strata sosial dan agama, hal ini tentu perlu pemahaman akan keberagaman yang muncul pada tiap-tiap siswa.

Berdasarkan hasil pengembangan diperoleh komponen bahan ajar Bahasa Indonesia berbasis multikultural terdiri dari halaman sampul, kata pengantar, daftar isi, latar belakang, deskripsi singkat, kompetensi inti, peta konsep, manfaat, kegiatan pembelajaran subtema 1 jenisjenis pekerjaan yang memuat kegiatan pada pembelajaran 1, pembelajaran 3, pembelajaran 4, pembelajaran 6, selanjutnya kegiatan pembelajaran subtema 2 pekerjaan di sekitarku yang memuat kegiatan pada pembelajaran 1, pembelajaran 3 , pembelajaran 4 , pembelajaran 6 , kemudian kegiatan pembelajaran subtema 3 pekerjaan orang tuaku yang memuat kegiatan pada pembelajaran 1, pembelajaran 3, pembelajaran 4, pembelajaran 6 , glosarium, daftar Pustaka, dan kunci jawaban. Bahan ajar Bahasa Indonesia berbasis multikultural ini bisa digunakan untuk belajar siswa secara mandiri dan kelompok maupun dengan bimbingan guru dalam pembelajaran. Adapun bahan ajar Bahasa Indonesia berbasis multikultural dapat dilihat pada gambar 2 sebagai berikut.

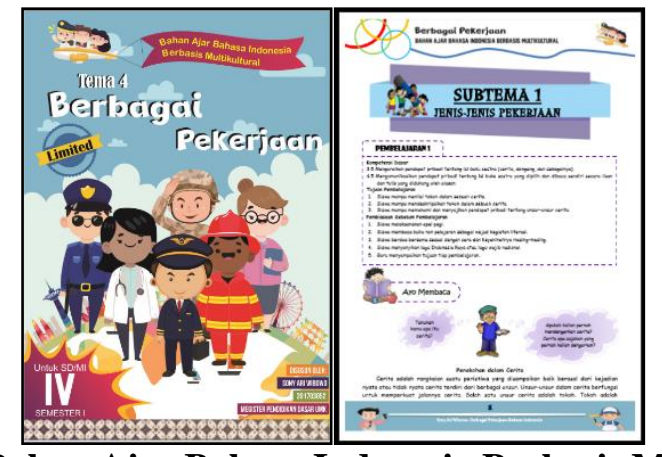

Gambar 2. Bahan Ajar Bahasa Indonesia Berbasis Multikultural.

Data uji keefektifan bahan ajar Bahasa Indonesia berbasis multikultural didapat dari kegiatan yang diberikan kepada siswa sesuai dengan bahan ajar yang dikembangkan. Kelompok eksperimen yaitu SD 1 Karangnongko dan SD 1 Tritis, kemudian kelompok kontrol yaitu SD 1 Daren dan SD 3 Nalumsari. Kelompok eksperimen mendapat perlakuan berupa penggunaan bahan ajar Bahasa Indonesia berbasis multikultural, sedangkan kelompok kontrol tanpa adanya perlakuan. Nilai keterampilan berpikir kritis pada pembelajaran Bahasa Indonesia menggunakan bahan ajar Bahasa Indonesia berbasis multikultural tema 4 berbagai pekerjaan pada kelas IV sekolah dasar dapat dilihat pada tabel 1 sebagai berikut. 
Jurnal PAJAR (Pendidikan dan Pengajaran)

Volume 5 Nomor 2 Maret 2021 | ISSN Cetak : 2580 - 8435 | ISSN Online : 2614 - 1337

DOI : http://dx.doi.org/10.33578/pir.v5i2.8287

Tabel 1. Nilai Keterampilan Berpikir Kritis Kelompok Eksperimen dan Kelompok Kontrol

\begin{tabular}{cccc}
\hline No. & $\begin{array}{c}\text { Kategori } \\
\text { Nilai }\end{array}$ & $\begin{array}{c}\text { Kelompok } \\
\text { Eksperimen }\end{array}$ & $\begin{array}{c}\text { Kelompok } \\
\text { Kontrol }\end{array}$ \\
\hline 1. & $\begin{array}{c}\text { Nilai } \\
\text { Tertinggi }\end{array}$ & 92 & 82 \\
2. & $\begin{array}{c}\text { Nilai } \\
\text { Terendah }\end{array}$ & 76 & 76 \\
3. & $\begin{array}{c}\text { Rata-rata } \\
\text { Nilai }\end{array}$ & 86 & 79 \\
4. & Kriteria & Sangat Baik & Baik \\
\hline
\end{tabular}

Data tersebut lebih jelasnya disajikan dalam bentuk diagram batang seperti grafik sebagai berikut.

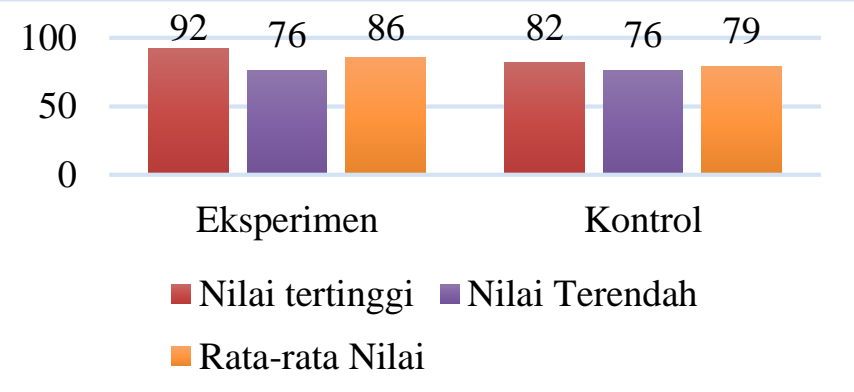

\section{Gambar 3. Diagram Nilai Keterampilan Berpikir Kritis Kelompok Eksperimen dan Kelompok Kontrol}

Berdasarkan Pada diagram tersebut menunjukkan bahwa rata-rata nilai keterampilan berpikir kritis siswa kelompok eksperimen lebih besar dibandingkan dengan rata-rata nilai keterampilan berpikiri kritis kelompok kontrol. Nilai rata-rata keterampilan berpikir kritis siswa pada kelompok eksperimen adalah 86 dengan nilai tertinggi yang dicapai siswa adalah 92 dan nilai terendah yang dicapai siswa adalah 76 . Kemudian nilai rata-rata keterampilan berpikir kritis siswa pada kelompok kontrol adalah 79 dengan nilai tertinggi yang dicapai siswa adalah 82 dan nilai terendah yang dicapai siswa adalah 76. Berdasarkan nilai rata-rata keterampilan berpikir kritis siswa tersebut menunjukkan bahwa penggunaan bahan ajar Bahasa Indonesia berbasis multikultural efektif digunakan untuk meningkatkan keterampilan berpikir kritis siswa dalam pembelajaran Bahasa Indonesia tema 4 berbagai pekerjaan pada kelas IV sekolah dasar di Kabupaten Jepara.

Untuk mendeskripsikan keefektifan bahan ajar Bahasa Indonesia berbasis multikultural tersebut digunakan uji-t berdasarkan nilai keterampilan berpikir kritis siswa pada kelompok eksperimen dan kelompok kontrol. Hasil uji efektifitas menunjukkan bahwa bahan ajar Bahasa Indonesia berbasis multikultural efektif digunakan dalam kegiatan pembelajaran. Hasil dari uji t pada kelompok eksperimen dan kontrol yaitu 8.994. Adapun hasil uji $\mathrm{t}$ didapatkan bahwa $\mathrm{t}_{\text {hitung }}>\mathrm{t}$ tabel yaitu $8.994>1.699$, maka sebagaimana dasar pengambilan keputusan dapat disimpulkan bahwa Ho ditolak dan Ha diterima. Berdasarkan uji t tersebut maka dapat disimpulkan bahwa penerapan bahan ajar Bahasa Indonesia berbasis multikultural efektif dan layak digunakan dalam meningkatkan keterampilan berpikir kritis siswa kelas IV sekolah dasar di Kabupaten Jepara.

Keefektifan bahan ajar Bahasa Indonesia berbasis multikultural diperkuat pula dengan hasil penelitian dari (Indrawini, 2017), dalam penelitiannya yang berjudul pengembangan bahan ajar tematik subtema ayo cintai lingkungan untuk siswa kelas IV SD. Penelitian dan pengembangan ini dilaksanakan di SDN Nogotirto. Tujuan 
penelitian ini adalah menghasilkan suplemen bahan ajar tematik untuk kelas IV subtema ayo cintai lingkungan, fokus kajiannya materi pelestarian lingkungan. Hasil penelitian menunjukkan bahwa tingkat kelayakan bahan ajar sangat tinggi. Bahan ajar yang dihasilkan memiliki tingkat kevalidan sebesar $87.45 \%$, kepraktisan sebesar $94.43 \%$, dan keefektifan sebesar $81.1 \%$. Dengan demikian dapat disimpulkan bahan ajar tematik yang dikembangkan peneliti layak digunakan sebagai bahan ajar dalam proses pembelajaran.

Penelitian dan pengembangan yang dilakukan oleh (Lestariningsih dan siti, 2017), tentang pengembangan bahan ajar tematikintegratif berbasis kearifan lokal untuk meningkatkan karakter peduli dan tanggung jawab. Tujuan penelitian ini adalah (1) menghasilkan bahan ajar tematik integratif berbasis kearifan lokal yang layak untuk meningkatkan karakter peduli dan tanggung jawab siswa, dan (2) mengetahui keefektifan bahan ajar tematik integratif berbasis kearifan lokal untuk meningkatkan karakter perduli dan tanggung jawab siswa. Hasil penelitian menunjukkan bahwa berdasarkan uji-t berpasangan didapat signifikansi untuk karakter peduli pada kelas eksperimen 1 sebesar 0.00 dan kelas eksperimen 2 sebesar 0.00 dan karakter tanggung jawab pada kelas eksperimen 1 sebesar 0.00 dan kelas eksperimen 2 sebesar 0.00 yang berarti ada perbedaan yang signifikan karakter peduli dan tanggung jawab siswa sebelum dan sesudah mengikuti pembelajaran dengan menggunakan bahan ajar tematik intergratif berbasis kearifan lokal. Dengan dapat disimpulkan bahan ajar yang dikembangkan efektif untuk meningkatkan karakter peduli dan tanggung jawab siswa.

Dari paparan tersebut dapat disimpulkan bahwa bahan ajar Bahasa Indonesia berbasis multikultural sangat dibutuhkan dalam menunjang proses pembelajaran dan meningkatkan keterampilan berpikir kritis siswa. Bahan ajar Bahasa Indonesia berbasis multikultural ini juga dapat mempermudah guru dalam menyampaikan materi.

\section{SIMPULAN DAN REKOMENDASI}

Berdasarkan hasil dan pembahasan yang telah diuraikan terhadap efektifitas penerapan bahan ajar Bahasa Indonesia berbasis multikultural untuk meningkatkan keterampilan berpikir kritis siswa, dapat diambil simpulan bahwa bahan ajar Bahasa Indonesia berbasis multikultural efektif dalam meningkatkan keterampilan berpikir kritis siswa. Hasil dari uji t pada kelompok eksperimen dan kontrol yaitu 8.994. Adapun hasil uji $\mathrm{t}$ didapatkan bahwa $\mathrm{t}$ hitung $>\mathrm{t}$ tabel yaitu $8.994>1.699$. Berdasarkan uji $\mathrm{t}$ tersebut maka dapat disimpulkan bahwa penerapan bahan ajar Bahasa Indonesia berbasis multikultural efektif dan layak digunakan untuk meningkatkan keterampilan berpikir kritis siswa kelas IV sekolah dasar di Kabupaten Jepara.

Berdasarkan simpulan tersebut, maka saran yang dapat disampaikan sebagai berikut (1) Guru hendaknya menerapkan inovasi-inovasi yang sesuai dengan pembelajaran yang dapat diterapkan pada proses pembelajaran sehingga pembelajaran menjadi lebih menyenangkan dan berkesan, (2) Guru hendaknya mampu mengembangkan bahan ajar dengan tema lainnya yang sesuai dengan kondisi lingkungan dan karakteristik siswa sehingga proses pengembangan kognitif, afektif, dan psikomotorik sesuai dengan yang diharapkan, (3) Peneliti lain hendaknya dapat mengembangkan bahan ajar dengan tema lainnya pada ruang lingkup sekolah yang lebih luas dan kondisi yang berbeda untuk mendapatkan hasil yang lebih sempurna.

\section{DAFTAR PUSTAKA}

Alismail, H., \& Ahmed. (2016). Multicultural Education: Teachers Perceptions and Preparation. Journal of Education and Practice. 7 (11): 139-146.

Hamalik, O. (2015). Proses Belajar Mengajar. Jakarta: PT Bumi Aksara.

Hanafy, M. S. (2015). Pendidikan Multikultural dan Dinamika Ruang Kebangsaan. Jurnal Diskursus Islam. 3 (1): 119-139.

Harijanto, M. (2007). Pengembangan Bahan Ajar untuk Peningkatan Kualitas Pembelajaran 
Program Pendidikan Pembelajar Sekolah Dasar. Jurnal Didaktika. 2 (1): 216-226.

Indrawini, T. (2017). Pengembangan Bahan Ajar Tematik Subtema Ayo Cintai Lingkungan untuk Siswa Kelas IV SD. Jurnal Pendidikan, 2 (11): 1489-1497.

Jatmiko, S dan Indratno, F. T. (2006). Pendidikan Multikultural yang Berkeadilan Sosial. Yogyakarta: Dinamika Edukasi Dasar.

Khairuddin, A. (2018). Epistemologi Pendidikan Multikultural di Indonesia. Jurnal Ijtimaiyah. 2 (1): 1-20.

Koparan, T. (2017). Analysis of Teaching Materials Developed by Prospective Mathematics Teachers and Their Views on Material Development. Malaysian Online Journal of Educational Technology. 5 (4): 8-28.

Kuswana, W. S. (2013). Taksonomi Berpikir. Bandung: PT Remaja Rosdakarya.

Lee, C. C. (2019). Invite Their Languages in: Community Based Literacy Practices with Multilingual African Immigrant Girls in New York City. International Journal of Multicultural Education. 21 (2): 1-22.

Lestariningsih, N., dan Suardiman, S. P. (2017). Pengembangan Bahan Ajar TematikIntegratif Berbasis Kearifan Lokal untuk Meningkatkan Karakter Peduli dan Tanggung Jawab. Jurnal Pendidikan Karakter. - (1): 86-99.

Nai, F. A. (2016). Teaching Material Development of Learning and Teaching Course Through Lesson Study Application for University Students. International Conference on Education. (-): 273-283.

Nurcahyono, O. H. (2018). Pendidikan Multikultural di Indonesia Analisis Sinkronis dan Diakronis. Jurnal Pendidikan, Sosiologi, dan antropologi. 2 (1): 105-115.

Nurjanah, S., Atmaja, H. T., dan Saraswati, U. (2017). Penanaman Nilai-nilai Multikulturalisme dalam Pembelajaran Sejarah Sub Materi Pokok Indonesia Zaman Hindu-Buddha pada Siswa Kelas $\mathrm{X}$ Madrasah Aliyah Negeri Purbalingga
Tahun Ajaran 2016/2017. Indonesian Journal of History Education. 5 (2): 6875.

Permana, T. I., Hindun, I., Rofi'ah, N. T., dan Ardianti, S. N. A. (2019). Critical Thinking Skills: its Correlation with Academic Ability, Mastering Concepts, and Analytical Skill of Undergraduate Student in Botany Class. Jurnal Pendidikan Biologi Indonesia. 5 (1): 1-8.

Prastowo, A. (2011). Panduan Kreatif Membuat Bahan Ajar Inovatif. Yogyakarta: DIVA Pres.

Schlein, C., dan Chan, E. (2012). Examining Students Experiences as a Foundation for Multicultural Curriculum Development. Journal of Curriculum Theorizing. 28 (2): 126-138.

Surya, M. (2016). Strategi Kognitif dalam Pembelajaran. Bandung: alfabeta.

Susanto, A. (2016). Teori Belajar dan Pembelajaran di Sekolah Dasar. Jakarta: Kencana Prenadamedia Group.

Susiana. (2017). Pengembangan Bahan Ajar Bahasa Indonesia Berbasis Budaya Lokal Malang Berdasarkan Kurikulum 2013 yang Disempurnakan untuk SMP/MTS Kelas VII Semester Gasal. Jurnal NOSI. 5 (2): $175-186$

Wahyuni, I. (2015). Pendidikan Multikultural upaya Memaknai Keragaman Bahasa di Indonesia. Jurnal Pemikiran Islam. 1 (1): 79-96.

Yaumi, M. (2016). Pendidikan Karakter: Landasan, Pilar, dan Implementasi. Jakarta: Kencana Prenadamedia Group. 